\title{
Tahap Define dalam Pengembangan Perangkat Pembelajaran Berbasis STEM untuk Meningkatkan Keterampilan Berpikir Tingkat Tinggi
} Mahasiswa

\author{
${ }^{1}$ Hikmawati, ${ }^{2}$ Chairunisyah Sahidu, ${ }^{3}$ Kosim, ${ }^{4}$ Sutrio, ${ }^{5}$ Gunawan
}

$1,2,3,4,5$ Prodi Pendidikan Fisika, FKIP, Universitas Mataram, Jln. Majapahit No.62 Mataram, NTB, 83125

Email Korespondensi: hikmawati@unram.ac.id

\begin{tabular}{|c|c|}
\hline Article Info & Abstract \\
\hline $\begin{array}{l}\text { Article History } \\
\text { Received: October } 2020 \\
\text { Revised: November } 2020 \\
\text { Published: December } 2020\end{array}$ & \multirow[b]{2}{*}{$\begin{array}{l}\text { Define Stage in the Development of STEM-Based Learning Devices to } \\
\text { Improve Students' Higher Order Thinking Skills. The purpose of this study is } \\
\text { to describe the results of the Define stage in the development of STEM } \\
\text { (Science, Technology, Engineering and Mathematics) -based learning devices } \\
\text { to improve students higher order thinking skills. The learning device } \\
\text { development model used is the four D model (Define, Design, Develop, } \\
\text { Disseminate). The Define stage is carried out to define and define learning } \\
\text { requirements. The steps that have been taken at the Define stage are front end } \\
\text { analysis, student analysis, task analysis, concept analysis, and formulation of } \\
\text { learning objectives. The results of the research for needs analysis are a } \\
\text { description of the competencies that students must have after taking physics } \\
\text { lectures, the learning approach used is based on STEM, the profile of } \\
\text { graduates to answer future challenges and demands. The results of research } \\
\text { for student analysis are descriptions of student characteristics which include } \\
\text { reasoning abilities, background knowledge, and levels of student cognitive } \\
\text { development. The results of research for task analysis are in the form of } \\
\text { module position maps. The results of the research for concept analysis are in } \\
\text { the form of a concept map about oscillations. The results of the study for the } \\
\text { formulation of learning objectives were a description of the competencies } \\
\text { consisting of attitudes, knowledge and skills. The conclusion from this research } \\
\text { is that the Define Stage has been completed so that the development stage of } \\
\text { learning devices can be carried out to the next stage, namely the Design stage. }\end{array}$} \\
\hline $\begin{array}{l}\text { Keywords } \\
\text { STEM, HOTS }\end{array}$ & \\
\hline Infor & Abstrak \\
\hline $\begin{array}{l}\text { Sejarah Artikel } \\
\text { Diterima: Oktober } 2020 \\
\text { Direvisi: November } 2020 \\
\text { Dipublikasi: Desember } 2020\end{array}$ & \multirow{2}{*}{$\begin{array}{l}\text { Tujuan penelitian ini adalah untuk mendeskripsikan hasil tahap Define dalam } \\
\text { pengembangan perangkat pembelajaran berbasis STEM (Science, Technology, } \\
\text { Engineering dan Mathematics) untuk meningkatkan keterampilan berpikir } \\
\text { tingkat tinggi mahasiswa. Model pengembangan perangkat pembelajaran yang } \\
\text { digunakan adalah model four D (Define, Design, Develop, Disseminate). Tahap } \\
\text { Define dilakukan untuk menetapkan dan mendefinisikan syarat-syarat } \\
\text { pembelajaran. Langkah-langkah yang telah dilakukan pada tahap Define adalah } \\
\text { analisis ujung depan, analisis mahasiswa, analisis tugas, analisis konsep, dan } \\
\text { perumusan tujuan pembelajaran. Hasil penelitian untuk analisis kebutuhan } \\
\text { yaitu deskripsi tentang kompetensi yang harus dimiliki mahasiswa setelah } \\
\text { mengikuti perkuliahan fisika, pendekatan pembelajaran yang digunakan } \\
\text { berbasis STEM, profil lulusan untuk menjawab tantangan dan tuntutan masa } \\
\text { depan. Hasil penelitian untuk analisis mahasiswa yaitu deskripsi tentang } \\
\text { karakteristik mahasiswa yang meliputi kemampuan bernalar, latar belakang } \\
\text { pengetahuan, dan tingkat perkembangan kognitif mahasiswa. Hasil penelitian } \\
\text { untuk analisis tugas yaitu dalam bentuk peta kedudukan modul. Hasil } \\
\text { penelitian untuk analisis konsep yaitu dalam bentuk peta konsep tentang } \\
\text { Osilasi. Hasil penelitian untuk perumusan tujuan pembelajaran yaitu deskripsi } \\
\text { kompetensi yang terdiri atas sikap, pengetahuan, dan keterampilan. Simpulan } \\
\text { dari penelitian ini adalah Tahap Define telah selesai dilakukan sehingga tahap }\end{array}$} \\
\hline & \\
\hline
\end{tabular}


pengembangan perangkat pembelajaran dapat dilakukan ke tahap selanjutnya yaitu tahap Design.

Sitasi: Hikmawati, H., Sahidu, C., Kosim, K., Sutrio, S., Gunawan, G. (2020). Tahap Define dalam Pengembangan Perangkat Pembelajaran Berbasis STEM untuk Meningkatkan Keterampilan Berpikir Tingkat Tinggi Mahasiswa. Kappa Journal, 4(2), 149-157

\section{PENDAHULUAN}

Peraturan Menteri Pendidikan Dan Kebudayaan Republik Indonesia Nomor 3 Tahun 2020 Tentang Standar Nasional Pendidikan Tinggi (SN-Dikti) pada Pasal 1 menyatakan bahwa Kurikulum adalah seperangkat rencana dan pengaturan mengenai tujuan, isi, dan bahan pelajaran serta cara yang digunakan sebagai pedoman penyelenggaraan kegiatan pembelajaran untuk mencapai tujuan Pendidikan Tinggi. Junaidi, dkk (2020) menyebutkan bahwa kurikulum merupakan nyawa dari suatu program pembelajaran sehingga keberadaannya memerlukan rancangan, pelaksanaan, sert evaluasi secara dinamis sesuai perkembangan zaman, kebutuhan ilmu pengetahuan, teknologi dan seni (IPTEKS) serta kompetensi yang dibutuhkan oleh masyarkat pada abad ke-21, maupun pengguna lulusan perguruan tinggi. Kompetensi mahasiswa yang dibutuhkan sesuai dengan kecakapan Abad 21, dianataranya adalah keterampilan 4C yakni berpikir kritis dan memecahkan masalah (critical thinking and problem solving), bekerjasama (collaboration), berkreativitas (creativities), dan berkomunikasi (communication).

Siswanto, dkk (2018) memberikan saran bahwa pembelajaran yang disajikan sebaiknya dapat memotivasi peserta didik untuk berfikir kritis, logis, dan sistematis sesuai dengan karakteristik Fisika, serta memiliki kemampuan berpikir tingkat tinggi (higher order thinking skills atau HOTS). Novianti \& Sapiruddin (2019) berpendapat bahwa berpikir kritis adalah keharusan, dalam usaha pemecahan masalah, pembuatan keputusan, sebagai pendekatan, menganalisis asumsi-asumsi, dan penemuan-penemuan keilmuan. Berpikir kritis diterapkan peserta didik untuk belajar memecahkan masalah secara sistematis dalam menghadapi tantangan, memecahkan masalah secara inovatif dan mendesain solusi yang mendasar. Proses berpikir kritis akan muncul jika ada keterbukaan pikiran dan kesabaran. Kemampuan ini akan membantu seseorang memahami sepenuhnya permasalahan yang ada. Berpikir kritis tetap menjaga keterbukaan pikiran selama dia mencari untuk mendapatkan alasan, bukti, dan kebenaran logika. Sapiruddin (2018) menyatakan bahwa kemampuan berpikir kritis sangat penting untuk mahasiswa, karena kemampuan berpikir yang rendah ini berdampak pada hasil belajar mahasiswa juga rendah. Dalam hal kemampuan kognitif, Anderson (2001) mengkategorikan tingkat berpikir ke dalam 6 kategori yaitun level $\mathrm{C} 1$ (Mengingat/Remember), C2 (Memahami/Understand), dan C3 (Menerapkan/Apply), level C4 (Menganalisis/Analyze), C5 (Mengevaluasi/Evaluate), dan C6 (Mencipta/Create).

Salah satu upaya yang dapat dilakukan untuk meningkatkan keterampilan berpikir tingkat tinggi mahasiswa adalah dengan menerapkan pembelajaran berbasis STEM. Menurut Permanasari (2016), penerapan STEM cocok digunakan pada pembelajaran sains termasuk fisika. Pembelajaran berbasis STEM dapat melatih mahasiswa dalam menerapkan pengetahuannya untuk membuat desain sebagai bentuk pemecahan masalah terkait lingkungan dengan memanfaatkan teknologi. Ercan et al (2016) menjelaskan bahwa STEM adalah singkatan dari science, technology, engineering dan mathematics. STEM merupakan pendekatan untuk pendidikan yang bertujuan untuk mengintegrasikan empat disiplin ilmu yang terpisah ini. Tujuan penelitian ini adalah mengembangkan perangkat pembelajaran Fisika Berbasis STEM (Science, Technology, Engineering dan Mathematics) untuk meningkatkan keterampilan berpikir tingkat tinggi mahasiswa. 


\section{METODE}

Model pengembangan perangkat pembelajaran dalam penelitian ini menggunakan model four-D (Define, Design, Develop, Disseminate) seperti yang disarankan oleh Thiagarajan, Semmel, dan Semmel dalam Trianto (2008) dan Ibrahim (2003). Model ini diadaptasi menjadi Model 4P (Pendefinisian, Perancangan, Pengembangan, dan Penyebaran).

Tahap Define bertujuan untuk menetapkan dan mendefinisikan syarat-syarat yang dibutuhkan dalam pembelajaran yang didasarkaan pada analisis kebutuhan, analisis siswa, analisis tugas, analisis konsep, perumusan tujuan pembelajaran. Tahap Design bertujuan untuk merancang draft Prototype perangkat pembelajaran berbasis STEM dengan melakukan penyusunan RPS, RTM, modul, media pembelajaran dan Instrumen Tes Keterampilan Berpikir Tingkat Tinggi atau Higher Order Thinking Skills (HOTS).

Tahap Develop bertujuan untuk menghasilkan produk Prototype perangkat pembelajaran yang telah direvisi berdasarkan hasil Validasi Pakar dan ujicoba terbatas. Perangkat pembelajaran yang dikembangkan layak digunakan apabila kualitas RPS, RTM, modul, media pembelajaran dan Instrumen Tes Keterampilan Berpikir Tingkat Tinggi atau Higher Order Thinking Skills (HOTS) berada dalam kategori baik. Keterlaksanaan pembelajaran dan aktivitas mahasiswa berkategori minimal baik, dan hasil belajar tuntas. Tahap Disseminate bertujuan untuk uji efektivitas penerapan produk prototype perangkat pembelajaran di kelas yang sesungguhnya melalui penelitian eksperimen. Makalah ini akan membahas hasil penelitian pada tahap Define.

\section{HASIL DAN PEMBAHASAN}

Hasil pengembangan perangkat pembelajaran berbasis STEM untuk tahap Define adalah sebagai berikut.

\section{ANALISIS KEBUTUHAN}

Undang-Undang Nomor 12 Tahun 2012 Pasal 35 ayat 2 mengamanatkan bahwa Kurikulum Pendidikan Tinggi dikembangkan oleh setiap Perguruan Tinggi dengan mengacu pada Standar Nasional Pendidikan Tinggi untuk setiap Program Studi yang mencakup pengembangan kecerdasan intelektual, akhlak mulia, dan keterampilan. Pada analisis kebutuhan ini akan diuraikan capaian pembelajaran lulusan, pendekatan pembelajaran, dan tantangan dan tuntutan masa depan.

1) CAPAIAN PEMBELAJARAN LULUSAN

Capaian pembelajaran lulusan Program Studi Pendidikan Fisika (dalam Buku Profil Program Studi Pendidikan Fisika, FKIP Universitas Mataram (2019) sebagai berikut.

\section{SIKAP}

a. Bertakwa kepada Tuhan Yang Maha Esa dan mampu menunjukkan sikap religious.

b. Menjunjung tinggi nilai kemanusiaan dalam menjalankan tugas berdasarkan agama, moral, dan etika.

c. Berkontribusi dalam peningkatan mutu kehidupan bermasyarakat, berbangsa, bernegara, dan kemajuan peradaban berdasarkan Pancasila.

d. Berperan sebagai warga negara yang bangga dan cinta tanah air, memiliki nasionalisme serta rasa tanggungjawab pada negara dan bangsa.

e. Menghargai keanekaragaman budaya, pandangan, agama, dan kepercayaan, serta pendapat atau temuan orisinal orang lain.

f. Bekerja sama dan memiliki kepekaan sosial serta kepedulian terhadap masyarakat dan lingkungan.

g. Taat hukum dan disiplin dalam kehidupan bermasyarakat dan bernegara.

h. Menginternalisasi nilai, norma, dan etika akademik.

i. Menunjukkan sikap bertanggungjawab atas pekerjaan di bidang keahliannya secara mandiri.

j. Menginternalisasi semangat kemandirian, kejuangan, dan kewirausahaan. 
k. Mempunyai ketulusan, komitmen, kesungguhan hati untuk mengembangkan sikap, nilai, dan kemampuan peserta didik dengan dilandasi oleh nilai-nilai kearifan lokal dan akhlak mulia serta memiliki motivasi untuk berbuat bagi kemaslahatan peserta didik dan masyarakat pada umumnya.

1. Memiliki rasa empati terhadap bencana alam

II. PENGUASAAN PENGETAHUAN

2.1 Penguasaan Substansi Bidang Keilmuan

a. Menguasai konsep teoretis fisika klasik dan modern (kuantum) secara umum.

b. Menguasai konsep umum, prinsip, dan aplikasi matematika, komputasi, dan fisika instrumentasi.

c. Menguasai pengetahuan operasional lengkap tentang fungsi, cara mengoperasikan instrumen fisika yang umum dan yang khusus untuk proses pembelajaran.

d. Menguasai prinsip, karakteristik, fungsi, dan aplikasi piranti lunak pada bidang fisika.

e. Menguasai pengetahuan tentang mitigasi bencana

2.2 Penguasaan Substansi Bidang Pendidikan

a. Menguasai metodologi penelitian pendidikan fisika.

b. Menguasai pengelolaan laboratorium untuk pembelajaran fisika.

c. Menguasai konsep teoretis pendidikan, perkembangan peserta didik (aspek fisik, intelektual, sosial-emosional, moral, spiritual, dan latar belakang sosial budaya) secara umum.

d. Menguasai konsep teoretis, prinsip, metoda,dan teknik:

- Pembelajaran fisika (physics teaching pedagogy) secara mendalam, yang meliputi: perencanaan, penyajian dan pengelolaan pembelajaran (kurikulum, sumber belajar, media, dan model pembelajaran), serta penilaian dan evaluasi proses dan hasil pembelajaran fisika.

- Pengembangan media pembelajaran fisika.

- Pengembangan alat laboratorium fisika untuk sekolah.

e. Menguasai konsep umum dan prinsip manajemen (perencanaan, operasional, pengawasan, evaluasi, dan perbaikan) laboratorium fisika untuk sekolah.

f. Menguasai konsep umum, prinsip, dan teknik pendampingan peserta didik.

g. Menguasai konsep-konsep umum dan metode penelitian kependidikan di bidang fisika.

III. KETERAMPILAN KHUSUS

3.1 Keterampilan Dalam Substansi Bidang Keilmuan.

a. Mampu membuat perangkat pembelajaran fisika secara mandiri sesuai dengan kebutuhan pengguna baik sekolah maupun masyarakat umum dengan menggunakan kaidah keilmuan dan prinsip desain instruktusional;

b. Mampu membuat perangkat pembelajaran fisika sekolah menengah melalui analisis materi subyek (pedagogical content knowledge) secara mandiri sesuai dengan kurikulum yang berlaku, prinsip- prinsip desain instruksional, pendekatan saintifik, memanfaatkan IPTEKS, dan lingkungan alam sekitar.

c. Mampu menganalisis masalah, menemukan sumber masalah, dan menyelesaikan masalah instrumentasi fisika dalam proses pembelajaran fisika dan masalah manajemen laboratorium fisika sesuai dengan kaidah keilmuan fisika.

d. Mampu menganalisis dan mengusulkan berbagai solusi alternatif yang ada terhadap permasalahan media belajar fisika dan masalah manajemen laboratorium fisika, serta menyimpulkannya untuk pengambilan keputusan yang tepat.

e. Mampu meningkatkan kualitas, efektivitas, dan efisiensi perangkat pembelajaran fisika secara mandiri dengan menggunakan kaidah keilmuan dan prinsip-prinsip inovasi. 
f. Mampu mempromosikan pentingnya pembelajaran fisika bagi siswa, orang tua siswa, maupun masyarakat umum dengan menggunakan media komunikasi konvensional atau mutakhir yang efektif dan relevan bagi sasaran.

g. Mampu berwirausaha berbasis sumber daya dan kearifan lokal dengan pendekatan etnosains

3.2 Keterampilan Dalam Substansi Bidang Kependidikan.

a. Mampu melaksanakan pembelajaran fisika sekolah menengah dengan pendekatan saintifik sesuai dengan karakteristik materi dan karakteristik siswa agar mampu mengembangkan kemampuan berfikir dan sikap ilmiah.

b. Mampu merencanakan dan mengelola sumberdaya dalam penyelenggaraan kelas dan penggunaan laboratorium untuk pembelajaran fisika.

c. Mampu melaksanakan kegiatan penilaian dan evaluasi proses dan hasil belajar yang sahih, andal, obyektif, dan praktis (sesuai dengan karakteristik pembelajaran fisika), yang meliputi:

- Penentuan aspek-aspek proses dan hasil belajar yang penting untuk dinilai dan dievaluasi.

- Penentuan prosedur sesuai dengan tujuan penilaian dan evaluasi.

- Pengembangan teknik dan instrumen penilaian dan evaluasi.

- Pelaksanaan evaluasi sesuai prosedur, teknik, dan instrumen yang ditentukan;

- Pelaksanaan proses moderasi penilaian.

- Analisis hasil penilaian proses dan hasil belajar untuk berbagai tujuan.

- Pengadministrasian penilaian proses dan hasil belajar secara berkesinambungan.

d. Mampu melakukan analisis reflektif terhadap pembelajaran (melalui pengamatan dan umpan balik dari peserta didik, orangtua peserta didik, serta rekan sejawat) untuk peningkatan kualitas pembelajaran.

e. Mampu melakukan penelitian tindakan kelas (action research) dengan pendekatan kuantitatif dan atau kualitatif untuk menyelesaikan masalah pembelajaran fisika dan membuat laporan hasil penelitian dalam bentuk artikel ilmiah.

f. Mampu melakukan pendampingan peserta didik dengan mempertimbangkan aspek sosio-kultural, serta bekerjasama dengan pihak-pihak yang berkaitan (orang tua dan teman-teman peserta didik, masyarakat sekitar, serta guru sejawat).

g. Mampu mengembangkan model pembelajaran mitigasi bencana di sekolah.

h. Mampu mengintegrasikan pembelajaran etnosains dengan pengembangan pariwisata halal

IV. KETERAMPILAN UMUM

a. Mampu menerapkan pemikiran logis, kritis, sistematis, dan inovatif dalam konteks pengembangan atau implementasi ilmu pengetahuan dan teknologi yang memperhatikan dan menerapkan nilai humaniora yang sesuai dengan bidang keahliannya.

b. Mampu menunjukkan kinerja mandiri, bermutu, dan terukur.

c. Mampu mengkaji implikasi pengembangan atau implementasi ilmu pengetahuan dan teknologi yang memperhatikan dan menerapkan nilai humaniora sesuai dengan keahliannya berdasarkan kaidah, tata cara dan etika ilmiah dalam rangka menghasilkan solusi, gagasan, desain atau kritik seni.

d. Mampu menyusun deskripsi saintifik hasil kajian tersebut di atas dalam bentuk skripsi atau laporan tugas akhir, dan mengunggahnya dalam laman perguruan tinggi.

e. Mampu mengambil keputusan secara tepat dalam konteks penyelesaian masalah di bidang keahliannya, berdasarkan hasil analisis informasi dan data.

f. Mampu memelihara dan mengembangkan jaringan kerja dengan pembimbing, kolega, sejawat baik di dalam maupun di luar lembaganya. 
g. Mampu bertanggungjawab atas pencapaian hasil kerja kelompok dan melakukan supervisi serta evaluasi terhadap penyelesaian pekerjaan yang ditugaskan kepada pekerja yang berada di bawah tanggungjawabnya;

h. Mampu melakukan proses evaluasi diri terhadap kelompok kerja yang berada dibawah tanggung jawabnya, dan mampu mengelola pembelajaran secara mandiri; dan

i. Mampu mendokumentasikan, menyimpan, mengamankan, dan menemukan kembali data untuk menjamin kesahihan dan mencegah plagiasi.

2) PENDEKATAN PEMBELAJARAN

Pembelajaran berbasis STEM (Science, Technology, Engineering dan Mathematics) memungkinkan mahasiswa belajar menerapkan konsep yang disintesis dalam masalah kehidupan nyata yang otentik sambil menggunakan keterampilan analitik abad ke-21 (Ntemngwa \& Oliver, 2018). Untuk menyiapkan peserta didik Indonesia memperoleh keterampilan abad 21, yaitu keterampilan cara berpikir melalui berpikir kritis, kreatif, mampu memecahkan masalah dan mengambil keputusan serta cara bekerja sama melalui kolaborasi dan komunikasi, maka pendekatan STEM diadopsi untuk menguatkan impelementasi Kurikulum Nasional yaitu Kurikulum 2013 (Noeraida \& Sulaeman, 2018).

Sebagai komponen dari STEM, sains adalah kajian tentang fenomena alam yang melibatkan observasi dan pengukuran sebagai wahana untuk menjelaskan secara obyektif alam yang selalu berubah. Terdapat beberapa domain utama dari sains pada jenjang pendidikan dasar dan menengah, yakni fisika, biologi, kimia, serta ilmu pengetahuan bumi dan antariksa (IPBA). Teknologi merujuk pada inovasi-inovasi manusia yang digunakan untuk memodifikasi alam agar memenuhi kebutuhan dan keinginan manusia, sehingga membuat kehidupan lebih nyaman dan lebih aman. Teknologi menjadikan manusia dapat melakukan perjalanan secara cepat, berkomunikasi langsung dengan orang di tempat yang berjauhan, memperoleh makanan sehat, dan alat-alat keselamatan. Rekayasa (engineering) merupakan pengetahuan dan keterampilan untuk memperoleh dan mengaplikasikan pengetahuan ilmiah, ekonomi, sosial, serta praktis untuk mendesain dan mengkonstruksi mesin, peralatan, sistem, material, dan proses yang bermanfaat bagi manusia secara ekonomis dan ramah lingkungan. Selanjutnya, matematika berkenaan dengan pola-pola dan hubunganhubungan, dan menyediakan bahasa untuk teknologi, sains, dan rekayasa (Wijayanti \& Fajriyah, 2018).

\section{3) TANTANGAN DAN TUNTUTAN MASA DEPAN}

Profil Lulusan Program Studi Pendidikan Fisika:

Sarjana pendidikan fisika yang mampu bertindak sebagai pendidik bidang fisika, peneliti bidang pendidikan fisika dan fisika, pengelola laboratorium, pengelola lembaga pendidikan, dan sebagai wirausaha. Deskripsi tentang profil tersebut dapat dilihat pada Tabel 1 berikut ini. 
Tabel 1. Profil Lulusan Program Studi Pendidikan Fisika

\begin{tabular}{ll}
\hline Profil & Deskripsi \\
\hline Pendidik Bidang Fisika & $\begin{array}{l}\text { Pendidik, fasilitator pembelajaran fisika yang inovatif yang } \\
\text { berorientasi pada kecakapan personal, sosial, dan akademik, serta } \\
\text { menguasai materi fisika yang baik. }\end{array}$ \\
& $\begin{array}{l}\text { Memiliki kemampuan menggunakan teknologi informasi dalam } \\
\text { proses pembelajaran fisika. }\end{array}$ \\
& Memiliki kemampuan merancang desain dan sistem instruksional \\
& sesuai dengan teori pembelajaran dan mengembangkannya \\
& melalui riset. Memiliki kemampuan berkomunikasi secara visual, \\
& oral maupun tertulis secara efektif. \\
\hline Peneliti & Menguasai metode penelitian fisika dan pendidikan fisika. \\
& $\begin{array}{l}\text { Pengkaji permasalahan bidang fisika dan pendidikan fisika serta } \\
\text { mampu mempublikasikannya dalam forum ilmiah }\end{array}$ \\
\hline Pengelola & $\begin{array}{l}\text { Memiliki kemampuan manajerial dalam pengelolaan } \\
\text { laboratorium fisika. }\end{array}$ \\
\hline Pengelola & Membaga \\
Pendidikan & Memiliki kemampuan manajerial dalam lembaga pendidikan. \\
\hline Wirausaha & Memiliki kemampuan membangun usaha sendiri dan mampu \\
& berkolaborasi dengan mitra usaha
\end{tabular}

2. ANALISIS PESERTA DIDIK

Mahasiswa di perguruan tinggi telah melewati jenjang Pendidikan anak usia dini, sekolah dasar, sekolah menengah pertama, dan sekolah menengah atas. Mahasiswa telah mempelajari sejumlah materi pokok dasar tentang fisika sebagai pengetahuan awal mereka pada jenjang Pendidikan di perguruan tinggi.

Mahasiswa tingkat awal berusia antara 18-20 tahun. Berdasarkan teori perkembangan kognitif Piaget (dalam Jufri, dkk. 2020), maka mahasiswa tingkat awal ini berada pada tahapan operasional formal. Karakteristik anak pada tahapan kognitif ini adalah:

a. Mampu memberikan alasan yang proporsional dan mengkombinasikan beberapa alasan

b. Mampu mengidentifikasi dan mengendalikan variable

c. Mampu memberikan alasan yang bersifat deduktif-hipotetik

d. Mampu berpikir reflektif

\section{ANALISIS TUGAS}

Sesuai dengan materi "Osilasi" maka diperoleh analisis sebagai berikut:

Kemampuan Akhir yang diharapkan yaitu mahasiswa dapat Menganalisis masalah fisika menggunakan konsep osilasi. Kegiatan Belajar yang akan dibahas pada modul yaitu Osilasi Pada Bandul, Osilasi Pada Pegas, dan Aplikasi Konsep Osilasi.

4. ANALISIS KONSEP

Hasil identifikasi konsep-konsep tentang materi osilasi menghasilkan peta konsep sebagai berikut. 


\section{OSILASI}

terjadi pada

$\begin{array}{ll}\text { Ayunan } & \text { Sistem } \\ \text { Bandul } & \text { Pegas }\end{array}$

memiliki besaran

memiliki energi

Amplitud Frekuensi

Periode

Energi

kinetik

Energi potensial

penerapan

$\begin{array}{lllll}\begin{array}{l}\text { Mengukur } \\ \text { percepatan }\end{array} & \begin{array}{l}\text { Percobaan } \\ \text { bandul }\end{array} & \text { Shockbreaker } & \text { Resonansi } & \text { Energi Mekanik } \\ \text { gravitasi } & \text { Faucoult } & & & \end{array}$

\section{PERUMUSAN TUJUAN PEMBELAJARAN}

Rumusan tujuan pembelajaran untuk materi "Osilasi" adalah mahasiswa dapat:

1) menjelaskan pengertian Osilasi

2) menjelaskan tentang amplitude, frekuensi dan periode

3) menjelaskan konsep ayunan bandul

4) menjelaskan konsep sistem pegas

5) menganalisis perbedaaan energi kinetic dengan energi potensial

6) menjelaskan tentang energi mekanik

7) menganalisis konsep osilasi pada kegiatan mengukur percepatan gravitasi bumi

8) menganalisis konsep osilasi pada percobaan bandul Foucault

9) menganalisis konsep osilasi pada alat shockbreaker

10) menganalisis konsep osilasi pada peristiwa resonansi

\section{KESIMPULAN}

Tahap define dalam pengembangan modul ini terdiri atas penetapan dan pendefinisian syarat-syarat pembelajaran. Langkah-langkahnya terdiri atas analisis kebutuhan, analisis siswa, analisis tugas, analisis konsep, dan perumusan tujuan pembelajaran. Tahap define telah selesai dilakukan sehingga tahap pengembangan modul dapat dilanjutkan ke tahap selanjutnya yaitu tahap Design.

\section{SARAN}

Peneliti dapat melanjutkan ke tahap selanjutnya yaitu Tahap Design yang bertujuan untuk merancang draft Prototype perangkat pembelajaran berbasis STEM dengan melakukan penyusunan RPS, RTM, modul, media pembelajaran dan Instrumen Tes Keterampilan Berpikir Tingkat Tinggi atau Higher Order Thinking Skills (HOTS).

\section{UCAPAN TERIMA KASIH}

Tim peneliti mengucapkan terima kasih kepada Universitas Mataram dan LPPM UNRAM yang telah memfasilitasi kegiatan penelitian ini, dan juga kepada semua pihak yang telah mendukung pelaksanaan kegiatan ini. 


\section{DAFTAR PUSTAKA}

Anderson, L.W., Krathwohl, D.R., Airasian, P.W., Cruikshank, K.A., Mayer, R.E., Pintrich, P.R., Raths, J., Wittrock, M.C. 2001. A Taxonomy for Learning, Teaching, and Assessing: A revision of Bloom's Taxonomy of Educational Objectives. New York: Pearson, Allyn \& Bacon.

Novianti, A.B., Sapirudin. 2019. Peningkatan Kemampuan Berpikir Kritis Melalui Cards Of The Formula Pada Perkuliahan Mekanika. Kappa Journal, Pendidikan Fisika, FMIPA, Universitas Hamzanwadi. 3(2), 105 - 112.

Ercan S., Altan EB., Taştan B., Dağ I. 2016. Integrating GIS into Science Classes to Handle STEM Education. Journal of Turkish Science Education, 13 (Special Issue), 3043.

Ibrahim, Muslimin. 2003. Pengembangan Perangkat Pembelajaran. Jakarta: Dirjen Dikdasmen Depdiknas.

Jufri AW, Qadri BA, Hikmawati, Maulyda MA, Sriwarthini NLPN. 2020. Belajar dan Pembelajaran: Modal Dasar Menjadi Guru Profesional. Mataram: Sanabil.

Junaidi A., dkk. Panduan Penyusunan Kurikulum Pendidikan Tinggi di Era Industri 4.0 untuk Mendukung Merdeka Belajar-Kampus Merdeka. Jakarta: Direktorat Jenderal Pendidikan Tinggi, Kementerian Pendidikan dan Kebudayaan.

Noeraida \& Sulaeman AA. 2018. UNIT PEMBELAJARAN STEM Mata Pelajaran IPA SMP Pembangkit Listrik Tenaga Minihidro (PLTMH). Jakarta: Pusat Pengembangan dan Pemberdayaan Pendidik dan Tenaga Kependidikan Ilmu Pengetahuan Alam.

Ntemngwa, C. \& Oliver, J.S. (2018). The Implementation of Integrated Science Technology, Engineering and Mathematics (STEM) Instruction using Robotics in the Middle School Science Classroom. International Journal of Education in Mathematics, Science and Technology (IJEMST), 6(1), 12-40. DOI:10.18404/ijemst.380617.

Permanasari A. 2016. STEM Education: Inovasi dalam Pembelajaran Sains. Prosiding Seminar Nasional Pendidikan Sains: "Peningkatan Kualitas Pembelajaran Sains dan Kompetensi Guru melalui Penelitian \& Pengembangan dalam Menghadapi Tantangan Abad-21" Surakarta, 22 Oktober 2016.

Peraturan Menteri Pendidikan Dan Kebudayaan Republik Indonesia Nomor 3 Tahun 2020 Tentang Standar Nasional Pendidikan Tinggi (SN-Dikti).

Sapiruddin. 2018. Implementasi Metode Scaffolding Melalui Pendekatan Problem Based Learning (PBL) Untuk Meningkatkan Kemampuan Berpikir Kritis Pada Mata Kuliah Fisika Statistik. Kappa Journal, Pendidikan Fisika, FMIPA, Universitas Hamzanwadi. 2(2), 16-20.

Siswanto, Slamet, W., Darjatiningsih, I., Mulyana, B. 2018. Fisika SMA. Jakarta: Direktorat Pembinaan Sekolah Menengah Atas, Direktorat Jenderal Pendidikan Dasar Dan Menengah, Kementerian Pendidikan Dan Kebudayaan.

Tim Penyusun. 2019. Profil Program Studi Pendidikan Fisika, Jurusan Pendidikan MIPA, FKIP, Universitas Mataram.

Trianto. 2008. Mendesain Pembelajaran Kontekstual (Contextual Teaching and Learning) di Kelas. Jakarta: Cerdas Pustaka.

UNDANG-UNDANG REPUBLIK INDONESIA NOMOR 12 TAHUN 2012 TENTANG PENDIDIKAN TINGGI.

Wijayanti A. \& Fajriyah K. 2018. Implementasi Stem Project Based Learning Untuk Meningkatkan Keterampilan Kerja Ilmiah Mahasiswa Calon Guru SD. Jurnal Pendidikan Sains (JPS), 6 (2), 69-69. 